\title{
Studies on Feeding Effect of Different Levels of Iodine in Salts at Consumption Level
}

\author{
A.K.Obidul Huq ${ }^{I^{*}}$, Md. Abu Zubair ${ }^{1}$, Md. Mohiduzzaman ${ }^{2}$, \\ Nazma Shaheen ${ }^{2}$ and Md. Aminul Haque Bhuyan ${ }^{2}$
}

\author{
${ }^{1}$ Food Technology and Nutritional Science, Mawlana Bhashani Science and Technology \\ University, Tangail-1902. \\ ${ }^{2}$ Institute of Nutrition and Food Science, University of Dhaka, Dhaka-1000.
}

\begin{abstract}
A prospective cohort study was undertaken to determine the optimum level of iodine in salts at household level which is best suitable to fulfill daily requirements and not excrete too much iodine in urine. A total number of 99 households of $3^{\text {rd }}$ categories and $4^{\text {th }}$ categories employees of Dhaka University, Bangladesh, living in university campus, were randomly divided into 3 groups. A total 778 causal urine samples from 351 individuals of the total households were collected and urinary iodine was estimated by the wet digestion method adapted by Gutekunst et.al. to determine the feeding effect of different levels of iodine in salts. The overall median urinary iodine were 202.7, 196.9 and $238.0 \mu \mathrm{g} / \mathrm{l}$ during baseline study and baseline consumption pattern showed that mean iodine content of salts were $41.6,34.1$ and $36.9 \mathrm{ppm}$ in group-1, group-2 and group-3 respectively. The first follow-up results showed that the overall median urinary iodine were $92.9,165.2$ and $265.6 \mu \mathrm{g} / \mathrm{l}$ and at that the their average iodine content of the experimental salts were $17.5,27.5$ and $45 \mathrm{ppm}$ in group-1, group-2 and group- 3 respectively. During first follow-up the majority $(72.7 \%)$ of the selected population were biochemically iodine deficient in group-1 whereas, almost all $(99.1 \%)$ were normal in group-2 and a remarkable fraction of the population (37.9\%) excreted excessive urinary iodine in group-3. The second follow-up findings indicates the overall median urinary iodine were $156.5,169.3$ and $180.3 \mu \mathrm{g} / \mathrm{l}$ in group-1, group-2 and group-3 respectively and at that time their experimental salt contained same amount of iodine (25-30 ppm). Iodine nutriture status of the study subjects during second follow-up revealed that almost all subjects $(97.3 \%)$ were normal in group- 1 , on the other hand, biochemically deficient or excessive excretion of urinary iodine was not observed in group- 2 and group- 3 i.e. all of the subjects were within the normal range (UI 100-299.99 $\mu \mathrm{g} / \mathrm{l}$ ) of urinary iodine excretion.
\end{abstract}

Key Word : Iodine Nutriture, Urinary Iodine and Biochemical Deficiency

\section{Introduction}

lodine is essential for normal growth and development and well being of man and animals. A very little amount of iodine is necessary everyday to produce adequate

Bangladesh Journal of Nutrition. Vol 18-19, December 2005-2006 Institute of Nutrition and Food Science, University of Dhaka-1000, Bangladesh.

·Corresponding author and email: duinfsobidul@yahoo.com 
amount of thyroxine $\left(\mathrm{T}_{4}\right)$ and triiodothyronine $\left(\mathrm{T}_{3}\right)$ hormones that regulate a wide variety of physiological processes in virtually all tissues of higher organisms. The optimum development of human brain from early embryonic to the adult stage is critically dependent on these hormones. A deficiency of the thyroid hormone whether in a severe iodine deficiency or congenitally defective thyroid, is associated with severe retardation of growth and maturation of almost all organ systems ${ }^{2}$. Iodine deficiency disorders (IDD) is a global public health problem. There is over whelming evidences to indicate that simply providing an adequate intake of iodine can effectively prevent IDD. Iodine can be supplemented in several forms, like iodized salt, iodized oil and iodized water. It was an established fact that iodine consumption through foods do not fulfill daily iodine requirement (adult $150 \mu \mathrm{g} / \mathrm{day}$ ), iodized salt or iodized water is then supplemented to fulfill daily iodine requirement. An intervention of salt iodization is the most effective public health approach for the elimination of IDD without side effects ${ }^{3}$.

Bangladesh has major public health problems especially relating to iodine deficiency of which causes IDD resulting goitre, physical and mental handicap and poor educability of children. To eliminate the IDD, the government of Bangladesh has passed the Universal Salt Iodization (USI) Law. Although substantial improvement has been achieved in the last 10 years, due to the increase in the consumption of iodized salt by households from $20 \%$ in 1994 to $73.8 \%$ in 2003 . But the third USI survey indicated that only $4.0 \%$ samples collected from factories contained iodine as per law, i.e. $45-50 \mathrm{ppm}$ and nearly $40 \%$ had $<20$ ppm iodine. Analysis of the results of first and second survey in 2003 further showed that an average $53.0 \%$ salt samples contained $<30 \mathrm{ppm}, 30.7 \%$ samples contained 30 to $<65 \mathrm{ppm}$ and $16.4 \%$ samples contained $\geq 65 \mathrm{ppm}^{4}$. Thus, salts are available in the market for human consumption, many of which contain different levels of iodine. So it is important to identify the optimum level of iodine in salts which is best suitable to fulfill the requirement to maintain good health. The appropriate level of iodine is not only important for health but also very important to ensure efficient use of iodine and avoid wastage or excess use of iodine, which would be detrimental for human health. Therefore, the present study was undertaken to determine the optimum level of iodine in salts at household level.

\section{Materials and Methods}

Present cross sectional study was undertaken to assess the appropriate level of iodine of iodized salts at household level, which covered 99 households from Dhaka University campus in capital city, Bangladesh. All members of those 99 selected household were included. Initially a total 351 respondents were selected. On the initial day all households member's casual urine and salt samples that they were consuming at that time were collected, simultaneously the left over salts in each household were taken away and given them new salts with known iodine content (estimated in the laboratory, 15-20 ppm to group-1, 25-30 ppm to group-2, 40-50 ppm to group-3) and asked them to take only that particular salts for 10 days. On the day 11 , their urine samples were again collected and simultaneously, new salts ( $25-30 \mathrm{ppm}$ containing salts to all households) were provided them for their consumption and advised them to take only those salts for 7 days. On the 
last day i.e. $18^{\text {th }}$ day, urine samples were again collected. A total of 99 salt samples were collected from 99 households. Salt samples were put in an individual disposable polythene bag, which was sealed off airtight and brought to IDD laboratory at the Institute of Nutrition and Food Science, University of Dhaka. Salt iodine was measured by titrametic method.

During the study period a total of 778 urine samples from 351 subjects of the 99 households were collected from the respondents. The urine samples were collected in disposable cups and were transferred to clean, dried, wide mouthed screw capped plastic bottles. Then the urine samples were carried in plastic cartons and brought to IDD laboratory at the Institute of Nutrition and Food Science (INFS), Dhaka University. The samples were stored in a deep freeze until analysis. Urinary iodine was measured by wet digestion method adapted by Gutekunst et.al.

Statistical Package for Social Science (SPSS) was used for data entry and data analysis. Microsoft excel was used for graphs and charts.

\section{RESULTS}

An experimental interventional group study was conducted to further confirm the optimum level of iodine in salts for local population to prevent IDD. Iodine consumption pattern of the experimental population randomly divided into three groups was presented in Table-I. Baseline results showed that the experimental population consumed salts initially with mean iodine content $41.6 \mathrm{ppm}, 34.1 \mathrm{ppm} \& 36.9 \mathrm{ppm}$ in group $-1,2$ \& 3 respectively. Accordingly, large variation between minimum and maximum iodine content of salts only prevails in group-1 as compared to group $2 \& 3$. During first intervention the mean iodine content of supplied experimental salt samples were 17.5 ppm, 27.5 ppm \& 45.0 ppm for group-1, 2 \& 3 respectively where as, mean iodine value of the salts supplied for all three groups was $27.5 \mathrm{ppm}$ during second time intervention.

Results of Median Urinary Iodine (MUI) level of the experimental populations was presented in table-II according to sex of 3 different intervention groups. In case of group1, baseline MUI was $202.7 \mu \mathrm{g} / \mathrm{l}$ (male 205.7 and female $200.0 \mu \mathrm{g} / \mathrm{l}$ ) and the range of urinary iodine excretion was varied from $24.5-927.5 \mu \mathrm{g} / \mathrm{l}$, when the selected subjects consumed salts which had mean iodine content of $41.6 \mathrm{ppm}$ with ranged $19.0-188.3$ ppm. After consumption of experimental salts contained $17.5 \mathrm{ppm}$ iodine (range 15.0$20.0 \mathrm{ppm}$ ) for ten days, the first follow-up MUI was $92.9 \mu \mathrm{g} / \mathrm{l}$ (male 92.8 and female 92.9 $\mu \mathrm{g} / \mathrm{l})$ and the range of urinary iodine excretion were $40.1-173.7 \mu \mathrm{g} / \mathrm{l}$. Again, the second follow-up MUI was $156.5 \mu \mathrm{g} / \mathrm{l}$ (male $157.2 \mu \mathrm{g} / \mathrm{l}$ and female $154.1 \mu \mathrm{g} / \mathrm{l}$ ) and the range of iodine were $93.9-248.0 \mu \mathrm{g} / \mathrm{l}$ after consumption of experimental salts for the next seven days during which their mean salt iodine intake was $27.5 \mathrm{ppm}$ (range $25-30 \mathrm{ppm}$ ).

In group-2, the baseline MUI was $196.9 \mu \mathrm{g} / 1$ (male 196.9 and female $196.9 \mu \mathrm{g} / \mathrm{l}$ ) and the range of urinary iodine excretion were $53.5-482.7 \mu \mathrm{g} / \mathrm{l}$, during that time their mean salt iodine intake was $34.1 \mathrm{ppm}$ and the range of salt iodine content were varied from $14.0-63.1 \mathrm{ppm}$. After consumption of experimental salts containing $27.5 \mathrm{ppm}$ iodine 
(range 25.0-30.0 ppm) for ten days the first follow-up MUI was $165.2 \mu \mathrm{g} / 1$ (male 169.6 and female $160.6 \mu \mathrm{g} / \mathrm{l}$ ) and the urinary iodine excretion were ranged from $101.2-355.1$ $\mu \mathrm{g} / \mathrm{l}$. Again after being fed with experimental salts for next seven days the second followup MUI was $169.3 \mu \mathrm{g} / \mathrm{l}$ (male $173.0 \mu \mathrm{g} / \mathrm{l}$ and female $167.8 \mu \mathrm{g} / \mathrm{l}$ ) and the range of iodine were $114.3-249.3 \mu \mathrm{g} / \mathrm{l}$, at that time their mean salt iodine intake was $27.5 \mathrm{ppm}$ (range 25-30 ppm).

In group-3, the baseline MUI was $238.0 \mu \mathrm{g} / \mathrm{l}$ (male $244.5 \mu \mathrm{g} / \mathrm{l}$ and female 235.8 $\mu \mathrm{g} / \mathrm{l})$ and the range of urinary iodine excretion were $62.6-811.6 \mu \mathrm{g} / \mathrm{l}$, during that time their mean salt iodine intake was $45.0 \mathrm{ppm}$ and the range of salt iodine were $40.0-50.0$ ppm.

After being fed with experimental salts containing $45.0 \mathrm{ppm}$ iodine (range 40.0 $50.0 \mathrm{ppm}$ ) for ten days the first follow-up MUI was $265.6 \mu \mathrm{g} / 1$ (male $268.5 \mu \mathrm{g} / 1$ and female $263.9 \mu \mathrm{g} / \mathrm{l}$ ) and the range of urinary iodine were varied from $118.8-733.7 \mu \mathrm{g} /$. Again, the second follow-up MUI was $180.3 \mu \mathrm{g} / \mathrm{l}$ (male $176.7 \mu \mathrm{g} / \mathrm{l}$ and female 180.6 $\mu \mathrm{g} / \mathrm{l})$ after being fed with experimental salts for next seven days and the range of iodine were 129.2 - $291.6 \mu \mathrm{g} / \mathrm{l}$, at that time their mean salt iodine intake was $27.5 \mathrm{ppm}$ (range 25-30 ppm).

Table III shows the distribution of the study subjects according to iodine nutriture status of three different groups. Baseline iodine nutriture status showed that severely deficient was not observed in any interventional group. Only one moderately deficient subject was detected in group-1 whereas none was identified in group 2 \& 3 . Furthermore, 3, 7 \& 8 mild iodine deficient subjects were observed in group $-1,2 \& 3$ respectively. Optimal level of urinary iodine was detected among 54, 56 \& 29 subjects of group-1, 2 \& 3 respectively, whereas, more than adequate level of iodine was observed among 46, 41 \& 47 subjects of group-1, 2 \& 3 respectively. Again 13, 17 \& 29 subjects showed excessive level of urinary iodine among group $-1,2 \& 3$ respectively. Table IV shows the distribution of the subjects according to iodine status during the first follow-up. Comparatively a higher percentage $(37.9 \%)$ of excessive urinary iodine excretion i.e. $\geq 300.00 \mu \mathrm{g} / 1$ was observed in group-3. No deficiency case was observed in group-2 \& 3 , on the other hand, a higher level of deficiency $(72.7 \%)$ cases were detected in group- 1 . Table $\mathrm{V}$ shows the distribution of the study population according to urinary iodine status during second follow-up. Any single case of severe iodine deficiency or excessive urinary iodine excretion was not observed in any interventional groups. Only $2.7 \%$ of mild iodine deficiency was found in group-1 and rest of all was normal. The prevalence of biochemically deficient subjects were decreased significantly from $72.7 \%$ to $2.7 \%$ in group- 1 , while in group- $2 \& 3$, there was no perceptible change $(0.0 \%$ and $0.0 \%)$.

Figure I shows the impact of different amounts of iodine in salt on MUI in total subjects of households by group. In group-1, the overall median urinary iodine was 202.7, 92.9 and $156.5 \mu \mathrm{g} / \mathrm{l}$ at baseline, the first and the second follow-up respectively; and the average iodine content of salts were 41.6, 17.5 and $27.5 \mathrm{ppm}$ at baseline, first and second intervention respectively. In group-2, the overall median urinary iodine was 
$196.9,165.2$ and $169.3 \mu \mathrm{g} / \mathrm{l}$ at baseline, the first and the second follow-up respectively and the iodine content of baseline salts was 34.1, and during the first and second followup average salt iodine was the same $(27.5 \mathrm{ppm})$. In group- 3 , the overall median urinary iodine was $238.0,265.6$ and $180.3 \mu \mathrm{g} / \mathrm{l}$ at baseline, the first and the second follow-up respectively; and the iodine content of salts were $36.9,45.0$ and $27.5 \mathrm{ppm}$ at baseline, the first and the second follow-up respectively.

\section{Discussion}

Salt iodization involves the addition of a small quantity of iodine per $\mathrm{kg}$ of salt in the form of potassium iodide or potassium iodate. It was found that school and college students and pregnant women consumed $40-60 \mathrm{ppm}$ iodine and excreted 200-400 $\mu \mathrm{g}$ iodine/L urine ${ }^{5}$. Recently it was also said that higher amount of iodine excretion $(>300 \mu \mathrm{g} / \mathrm{l}$ ) by urine everyday for a long time is not good sign, it may have adverse effect on health in a long run. The man who have a history of some pre-existing thyroid disorder, prolonged ingestion of iodine (200 mg or more daily for weeks or months) eventually leads to hypothyroidism and usually to a degree of thyroid enlargement (iodide Goitre) ${ }^{6}$.

WHO, UNICEF and ICCIDD have recognized that a chronically iodine deficient population increase their iodine intake above their normal consumption, there is a risk that a small number of individuals, particularly people over 40 years of age with longstanding, nodular and potentially autonomous goitres, will suffer from a condition known as "Jod Basedow" or iodine-induced hyperthyroidism (IIH). According to this group of susceptible individuals, the increased iodine intake precipitates hyperthyroidism i.e. an abnormal condition induced excess secretion of thyroid hormones by the thyroid gland?

The baseline median urinary iodine (MUI) was $211.4 \mu \mathrm{g} / \mathrm{l}$ (male $219.9 \mu \mathrm{g} / \mathrm{l}$ and female $210.5 \mu \mathrm{g} / \mathrm{l}$ ) and their mean baseline salt iodine intake was $37.53 \mathrm{ppm}$. A study on pregnant women visiting the antenatal clinic of "MCHTT" during November 2003 to April 2004 were studied and the overall median urinary iodine was 218.6 and $213.8 \mu \mathrm{g} / \mathrm{l}$ initially, and then the first time follow-up; and their mean iodine content of salts were 38.5 and $35.9 \mathrm{ppm}$ during the initial contact and then the first time follow-up respectively ${ }^{4}$. So it appears that when the salt iodine intake was near about $37.5 \mathrm{ppm}$, the median urinary iodine value was observed was more than adequate.

After being fed with different types of experimental salts containing various amount of iodine, (15-20 ppm for group-1, 25-30 ppm for group-2 and 40-50 ppm for group-3) for the duration of ten days, the overall median urinary iodine were $92.9,165.2$ and 265.6 $\mu \mathrm{g} / \mathrm{l}$ in group-1, group-2 and group-3 respectively and $72.7,0.0$ and $0.0 \%$ of the study subjects were deficient in respective groups. Again $0.0,0.9$ and $37.9 \%$ subjects excreted $\geq 300 \mu \mathrm{g}$ iodine $/ \mathrm{L}$ urine in group- 1 , group- 2 and group- 3 respectively.

After feeding all the subjects of three groups with the same amount of iodine contained in the experimental salts (25-30 ppm for each group) for next seven days, the overall median urinary iodine were $156.5,169.3$ and $180.3 \mu \mathrm{g} / \mathrm{l}$ in group-1, group-2 and 
group-3 respectively. The second time follow-up, the median urinary iodine in total subjects was $165.1 \mu \mathrm{g} / \mathrm{l}$ (male $159.5 \mu \mathrm{g} / \mathrm{l}$ and female $165.3 \mu \mathrm{g} / \mathrm{l}$ ). And only $2.7 \%$ of the subjects were deficient in group- 1 but no deficient were found in group-2 and group-3. Again no subjects excreted $\geq 300 \mu \mathrm{g}$ iodine $/ \mathrm{L}$ urine in all the three groups.

Finally, it is concluded that salt containing $15-20 \mathrm{ppm}$ of iodine in households is not sufficient to fulfill the requirements of all the categories of subjects in a household. On the other hand, salt containing $40-50 \mathrm{ppm}$ of iodine in households is more than enough for all types of subjects in the households. But the salt containing $25-30 \mathrm{ppm}$ of iodine in households is best suitable to fulfill the normal requirements of all categories of subjects in a household and to prevent too much iodine excretion in urine. Therefore, all the evidence indicates that iodine should be mixed in factories in such a way that before being consumed in households, iodine content in salt should be present between 25-30 ppm.

Table 1. Iodine content of the salts consumed by three different intervention groups

\begin{tabular}{l|c|c|c|c}
\hline \multicolumn{1}{c}{ Times } & Salt iodine (ppm) & Group-1 & Group-2 & Group-3 \\
\hline Base line & Mean value & 41.6 & 34.1 & 36.9 \\
& Range & $19.0-188.3$ & $14.0-63.1$ & $16.0-55.1$ \\
\cline { 2 - 5 } First time & Mean value & 17.5 & 27.5 & 45.0 \\
intervention & Range & $15.0-20.0$ & $25.0-30.0$ & $40.0-50.0$ \\
\cline { 2 - 5 } $\begin{array}{l}\text { Second time } \\
\text { intervention }\end{array}$ & $\begin{array}{c}\text { Mean value } \\
\text { Range }\end{array}$ & 27.5 & 27.5 & 27.5 \\
\hline & & $25.0-30.0$ & $25.0-30.0$ & $25.0-30.0$ \\
\hline
\end{tabular}

Table 2. Median urinary iodine (MUI) level of the population according to sex of different intervention groups

\begin{tabular}{|c|c|c|c|c|c|c|c|c|c|c|}
\hline \multirow{2}{*}{ Times } & \multirow{2}{*}{$\begin{array}{l}\text { Urinary } \\
\text { iodine }\end{array}$} & \multicolumn{3}{|c|}{ Group-1 } & \multicolumn{3}{|c|}{ Group-2 } & \multicolumn{3}{|c|}{ Group-3 } \\
\hline & & Male & Female & Total & Male & Female & Total & Male & Female & Total \\
\hline \multirow{4}{*}{ Baseline } & Median $(\mu \mathrm{g} / \mathrm{l})$ & 205.7 & 200.0 & 202.7 & 196.9 & 196.9 & 196.9 & 244.5 & 235.8 & 238.0 \\
\hline & Minimum & 24.5 & 88.9 & 24.5 & 53.5 & 83.4 & 53.52 & 62.6 & 63.7 & 62.6 \\
\hline & Maximum & 927.5 & 404.4 & 927.5 & 405.6 & 482.7 & 482.7 & 811.6 & 742.0 & 811.6 \\
\hline & $\mathrm{n}$ & 63 & 54 & 117 & 60 & 61 & 121 & 49 & 64 & 113 \\
\hline \multirow{4}{*}{$\begin{array}{l}\text { First } \\
\text { follow- } \\
\text { up }\end{array}$} & Median $(\mu \mathrm{g} / \mathrm{l})$ & 92.8 & 92.9 & 92.9 & 169.6 & 160.6 & 165.2 & 268.5 & 263.9 & 265.6 \\
\hline & Minimum & 40.8 & 40.1 & 40.1 & 101.2 & 102.3 & 101.2 & 131.3 & 118.8 & 118.8 \\
\hline & Maximum & 173.7 & 165.4 & 173.7 & 273.2 & 355.1 & 355.1 & 591.9 & 733.7 & 733.7 \\
\hline & $\mathrm{n}$ & 52 & 58 & 110 & 53 & 58 & 111 & 46 & 57 & 103 \\
\hline \multirow{4}{*}{$\begin{array}{l}\text { Second } \\
\text { follow- } \\
\text { up }\end{array}$} & Median $(\mu \mathrm{g} / \mathrm{l})$ & 157.2 & 154.1 & 156.5 & 173.0 & 167.8 & 169.3 & 176.7 & 180.6 & 180.3 \\
\hline & Minimum & 110.5 & 93.9 & 93.6 & 120.7 & 114.3 & 114.3 & 129.2 & 133.3 & 129.2 \\
\hline & Maximum & 248.0 & 236.4 & 248.0 & 249.1 & 212.0 & 249.1 & 291.6 & 287.9 & 291.6 \\
\hline & $\mathrm{n}$ & 20 & 17 & 37 & 16 & 19 & 35 & 11 & 20 & 31 \\
\hline
\end{tabular}


Table 3. Distribution of iodine nutriture status of different intervention groups during baseline

\begin{tabular}{c|c|c|c|c}
\hline $\begin{array}{c}\text { Urinary iodine in } \\
\mu \mathrm{g} / 1\end{array}$ & Iodine nutriture & Group-1 & Group-2 & Group-3 \\
\hline$<20$ & Severe iodine deficiency & 0 & 0 & 0 \\
& & $(0.0)$ & $(0.0)$ & $(0.0)$ \\
$20-49.99$ & Moderate iodine & 1 & 0 & 0 \\
& deficiency & $(0.9)$ & $(0.0)$ & $(0.0)$ \\
$50-99.99$ & Mild iodine deficiency & 3 & 7 & 8 \\
& & $(2.6)$ & $(5.8)$ & $(7.1)$ \\
$<\mathbf{1 0 0 . 0 0}$ & Total & $\mathbf{4}$ & $\mathbf{7}$ & $\mathbf{8}$ \\
& deficiency & $(3.4)$ & $(5.8)$ & $(7.1)$ \\
$100-199.99$ & Optimal & 54 & 56 & 29 \\
& & $(46.2)$ & $(46.3)$ & $(25.7)$ \\
$200-299.99$ & More than & 46 & 41 & 47 \\
& adequate & $(39.3)$ & $(33.9)$ & $(41.6)$ \\
$\mathbf{1 0 0 . 0 0 - 2 9 9 . 9 9}$ & Total & $\mathbf{1 0 0}$ & 97 & $\mathbf{7 6}$ \\
& normal & $(\mathbf{8 5 . 5}$ & $(\mathbf{8 0 . 2})$ & $(\mathbf{6 7 . 2})$ \\
$\geq 300.00$ & Excessive & 13 & 17 & 29 \\
& & $(11.1)$ & $(14.0)$ & $(25.7)$ \\
\hline
\end{tabular}

Figures in the parentheses indicate percentage

Table 4. Distribution of first follow-up iodine nutriture status of different intervention groups of study subjects

\begin{tabular}{|c|c|c|c|c|}
\hline Urinary iodine in $\mu \mathrm{g} / 1$ & Iodine nutriture & Group-1 & Group-2 & Group-3 \\
\hline$<20$ & $\begin{array}{c}\text { Severe iodine } \\
\text { deficiency }\end{array}$ & $\begin{array}{c}0 \\
(0.0)\end{array}$ & $\begin{array}{c}0 \\
(0.0)\end{array}$ & $\begin{array}{c}0 \\
(0.0)\end{array}$ \\
\hline $20-49.99$ & $\begin{array}{l}\text { Moderate iodine } \\
\text { deficiency }\end{array}$ & $\begin{array}{c}2 \\
(1.8)\end{array}$ & $\begin{array}{c}0 \\
(0.0)\end{array}$ & $\begin{array}{c}0 \\
(0.0)\end{array}$ \\
\hline $50-99.99$ & $\begin{array}{l}\text { Mild iodine } \\
\text { deficiency }\end{array}$ & $\begin{array}{c}78 \\
(70.9)\end{array}$ & $\begin{array}{c}0 \\
(0.0)\end{array}$ & $\begin{array}{c}0 \\
(0.0)\end{array}$ \\
\hline$<100.00$ & $\begin{array}{c}\text { Total } \\
\text { deficiency }\end{array}$ & $\begin{array}{c}80 \\
(72.7)\end{array}$ & $\begin{array}{c}0 \\
(0.0)\end{array}$ & $\begin{array}{c}0 \\
(0.0)\end{array}$ \\
\hline $100-199.99$ & Optimal & $\begin{array}{c}30 \\
(27.3)\end{array}$ & $\begin{array}{c}87 \\
(78.4)\end{array}$ & $\begin{array}{c}24 \\
(23.3)\end{array}$ \\
\hline $200-299.99$ & $\begin{array}{l}\text { More than } \\
\text { adequate }\end{array}$ & $\begin{array}{c}0 \\
(0.0)\end{array}$ & $\begin{array}{c}23 \\
(20.7)\end{array}$ & $\begin{array}{c}40 \\
(38.8)\end{array}$ \\
\hline $100.00-299.99$ & $\begin{array}{c}\text { Total } \\
\text { normal }\end{array}$ & $\begin{array}{c}30 \\
(27.3)\end{array}$ & $\begin{array}{c}110 \\
(99.1)\end{array}$ & $\begin{array}{c}64 \\
(62.1)\end{array}$ \\
\hline$\geq 300.00$ & Excessive & $\begin{array}{c}0 \\
(0.0)\end{array}$ & $\begin{array}{c}1 \\
(0.9)\end{array}$ & $\begin{array}{c}39 \\
(37.9)\end{array}$ \\
\hline
\end{tabular}

Figures in the parentheses indicate percentage 
Bangladesh J. Nutr. Vol. 18-19, December 2005-2006

Table-5. Distribution of second follow-up iodine nutriture status of different intervention groups of study subjects.

\begin{tabular}{|c|c|c|c|c|}
\hline Urinary iodine in $\mu \mathrm{g} / \mathrm{I}$ & Iodine nutriture & Group-1 & Group-2 & Group-3 \\
\hline \multirow[t]{2}{*}{$<20$} & Severe iodine & 0 & 0 & 0 \\
\hline & deficiency & $(0.0)$ & $(0.0)$ & $(0.0)$ \\
\hline \multirow[t]{2}{*}{$20-49.99$} & Moderate iodine & 0 & 0 & 0 \\
\hline & deficiency & $(0.0)$ & $(0.0)$ & $(0.0)$ \\
\hline \multirow[t]{2}{*}{$50-99.99$} & Mild iodine & 1 & 0 & 0 \\
\hline & deficiency & $(2.7)$ & $(0.0)$ & $(0.0)$ \\
\hline \multirow[t]{2}{*}{$<100.00$} & Total & 1 & 0 & 0 \\
\hline & deficiency & (2.7) & $(0.0)$ & $(0.0)$ \\
\hline \multirow[t]{2}{*}{$100-199.99$} & Optimal & 32 & 31 & 22 \\
\hline & & $(86.5)$ & $(88.6)$ & (71.0) \\
\hline \multirow[t]{2}{*}{ 200-299.99 } & More than & 4 & 4 & 9 \\
\hline & adequate & $(10.8)$ & (11.4) & $(29.0)$ \\
\hline \multirow[t]{2}{*}{$100.00-299.99$} & Total & 36 & 35 & 31 \\
\hline & normal & (97.3) & (100.0) & (100.0) \\
\hline \multirow[t]{2}{*}{$\geq 300.00$} & Excessive & 0 & 0 & 0 \\
\hline & & $(0.0)$ & $(0.0)$ & $(0.0)$ \\
\hline
\end{tabular}

Figures in the parentheses indicate percentage

Figure 1: Impact of different amounts of iodine in salts on median urinary iodine in total subjects

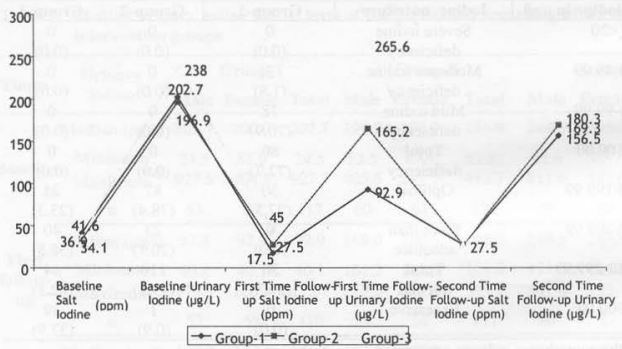

\section{Acknowledgements}

The authors thankfully acknowledge the invaluable contribution of Late Professor Dr. Quazi Salamatullah in the whole procedure of laboratory facilities and subsequent initial guidance in the preparation of the script. 


\section{References}

1. Pandav CS, Mohan E, Karmarkar MG, Subramania P \& Nath LM . Iodine deficiency in India. Natl Med J India 1989, 2:18.

2. Hetzel BS. S. O. S for a Billion-The Nature and Magnitude of Iodine Deficiency Disorders. In: S.O.S for a Billion-The Conquest of Iodine Deficiency Disorders. (Hetzel BS \& Pandav CS, Eds.) Oxford University Press, New Delhi, 1994.

3. Ahmed K \& Jahan K. Letter to the editor. In: Bangladesh Journal of Nutrition. INFS, Dhaka, 1975.

4. Salamatullah Q. Sentinel urinary iodine surveillance on pregnant women. IDD News Letter, $2004,8: 3$.

5. Salamatullah Q. Sentinel urinary iodine surveillance on pregnant women. IDD News Letter, 2002 7:3.

6. Goodhart RS, Shills ME, Lea \& Febiger. Modern Nutrition Health and Diseases Diet therapy. (In: Henry Kimpton, Eds.) 5th ed, London, 1976.

7. Roti E \& Vagenakis G. Effect of excess iodide: clinical aspects. In: The thyroid. A clinical and fundamental text. (Braverman L \& Utiger RD Eds.) Philadelphia, 1991 